\title{
Professora Carlinda Shüller Liebling: um pioneirismo singular no Colégio Centenário
}

Ela chamaria os pesquisadores de "loucos": [...] ela iria dizer, 'vocês estão loucos! Eu não tenho nada pra contar pra vocês, não quero saber de nada disso' [...] a mãe era muito tímida [...]". (Lúcia Liebling Copite)

\author{
Norberto da Cunha Garin ${ }^{1}$ \\ Edgar Zanini Timm²
}

\section{RESUMO}

O presente artigo resulta de uma pesquisa intitulada "Vida de professores: quando antigos mestres da educação continuam a ensinar". A pesquisa, realizada com a metodologia das Histórias de Vida, desenvolveu-se no Grupo de Pesquisa CNPq/IPA Educação e Inclusão, estando vinculada ao Núcleo de Estudos em Educação, Espiritualidade e Histórias de Vida (NEEHV) do Centro Universitário Metodista (IPA). Um dos educadores estudados foi Carlinda Shüller Liebling, ex-aluna interna e posteriormente professora no Colégio Centenário, mantido pela Igreja Metodista em Santa Maria, RS, Brasil. O estudo evidenciou, entre outros entendimentos construídos em seu processo, que a tenacidade, a perseverança, o entusiasmo e a construção, manutenção e desenvolvimento cotidiano de uma forte vontade de sentido existencial marcaram sua vida no magistério e podem servir, não como modelo único, mas como um exemplo de como é possível sentir-se bem na docência.

\section{PALAVRAS CHAVE}

Professora Carlinda Shüller Liebling. Colégio Centenário. Igreja Metodista. Histórias de Vida de Professores. Bem-estar na docência.

\footnotetext{
${ }^{1}$ Bacharel em Teologia (FT/IMS), licenciado em Filosofia (UPF), Mestre e Doutor em Teologia (EST), professor e pesquisador no Programa de Pós-Graduação em Reabilitação e Inclusão do Centro Universitário Metodista - IPA, em Porto Alegre, RS. Pesquisador do Grupo de Pesquisa CNPq/IPA Educação e Inclusão, coordenador do Núcleo de Estudos em Educação, Espiritualidade e Histórias de Vida (NEEHV/IPA).

${ }^{2}$ Licenciado em Educação Física (ESEF/UFPEL) e em Filosofia (PUCRS), Mestre e Doutor em Educação (PUCRS), professor e pesquisador no Programa de Pós-Graduação em Reabilitação e Inclusão e no Programa de Pós-Graduação em Biociências e Reabilitação do Centro Universitário Metodista - IPA, em Porto Alegre, RS. Pesquisador do Grupo de Pesquisa CNPq/IPA Educação e Inclusão, coordenador do Núcleo de Estudos em Educação, Espiritualidade e Histórias de Vida (NEEHV/IPA) e membro pesquisador do GRUPRODOCI CNPq/PUCRS.
} 


\section{ABSTRACT}

This article is the result of a research entitled "Teachers' life: when old education masters continue to teach". The research, done with the methodology of the Life Stories, was developed in the Research Group CNPq/ IPA Education and Inclusion, being linked to the Education, Spirituality and Life Stories Studies Core (NEEHV, in portuguese) of the Methodist Academic Center (IPA, in portuguese). One of the studied educators was Carlinda Shüller Liebling, former student and after teacher at Centenário School, sustained by the Methodist Church in Santa Maria, RS, Brazil. The study showed, among other arrangements constructed in the process, the tenacity, the perseverance, the enthusiasm and the construction, maintenance and routine development of a strong will to existential sense marked her life in mastership and it can serve not as an only model, but as an example of how is possible to feel good in teaching.

\section{KEYWORDS}

Teacher Carlinda Shüller Liebling. Centenário School. Methodist Church. Teachers' Life Stories. Well-being in teaching. 


\section{Introdução}

Trabalhar com histórias de vida é sempre algo que nos surpreende. Cada vida é uma singularidade, tem sempre algo novo a nos dizer e a nos fazer pensar. Histórias são plurais, e, por isso mesmo, merecem ser vistas também de um modo plural. Por mais que tenhamos, de antemão, feito nossas escolhas para um modo de ouvir, registrar, refletir, expressar o que ouvimos (e sentimos) durante as narrativas, observações, entrevistas, apreciação de documentos textuais ou de imagens, sempre haverá espaço para o inédito, para aquilo que é construído durante o caminho. Isso inclui desde a invenção de um jeito diferente de olhar uma imagem, até o modo como será apresentada a história que os autores criaram das histórias que compõem a história de vida da pessoa que narra de si ou de quem dela narra. Resulta, assim, um primeiro entendimento para quem trabalha com a metodologia das histórias de vida em pesquisa (Auto) Biográfica: o escrito será sempre uma, entre as múltiplas possibilidades que se tem de escrever de uma história de vida. Não se terá a pretensão de apresentar A História de Vida de alguém. Estará, isto sim, sendo apresentada apenas uma história, entre as muitas possíveis de serem escritas. No caso de a pessoa já ter falecido, a complexidade se amplia, pois a história de vida a ser construída depende da narrativa de outros olhares, de outras histórias de vida que, de algum modo, estiveram ou estão implicadas com essa da qual se estuda, e que, gentilmente, estão a compartilhar suas memórias com o autor. No compartilhamento das memórias de quem conviveu com a pessoa, observa-se a oportunidade de uma reelaboração do vivenciado. Isto muitas vezes pode se dar pelo distanciamento do tempo do que é narrado, mas, também, principalmente pelo sentimento que volta por ocasião dessas (re) lembranças. Estudos realizados por MOSQUERA (1978); MOSQUERA; STOBÄUS; TIMM (2009), ERIKSON (1998); BAUMAN (2004; 2001); PAPALIA; OLDS; FELDMAN (2010), ABRAHÃO (2014; 2013; 2010), TIMM (2014; 2010), ABRAHÃO; TIMM (2015), TIMM; GARIN; SILVA; FOGAÇA (2016), GARIN (2007), DIAS; GARIN; TIMM (2011), FRANKL (2015) foram importantes na composição do quadro teórico para reflexão durante os estudos realizados no desenvolvimento da Pesquisa "Vida de professores: quando antigos mestres da educação continuam a ensinar".

Este texto, originado no contexto dessa pesquisa, apresenta uma história entre as muitas histórias possíveis de serem escritas ao se estudar as muitas histórias que compõem, em seu conjunto, a história de vida de Carlinda Shüller Liebling, primeira professora formada pelo Colégio Metodista Centenário, ${ }^{3}$ de Santa Maria, no Rio Grande do Sul. É esta uma história que construímos, de sua história de vida, valendo-nos basicamente de depoimentos e de um livro por ela publicado.

A professora Carlinda participou de históricos momentos iniciais do Colégio Centenário. Para ilustrar, destacamos dois deles já no começo deste texto. Um deles foi por ocasião da definição das cores oficiais do colégio: numa manhã chuvosa de março de 1923, atendendo ao sinal que chamava para o café, as centenaristas se reuniram para cantar o "Parabéns a você!" por um ano de fundação da escola. Nesse momento, houve uma interrupção, porque uma das alunas internas ${ }^{4}$ queria aperfeiçoar a decoração da mesa do bolo:

Naquele momento, a aluna Maria Cunha, [...] exclamou: "Esperem um momento, não apaguem a velinha, vou buscar uns galhos verdes para enfeitar a mesa [...] Tudo tão branco e tão verde, simbolizando a pureza e a esperança. Por que não adotar estas cores como as cores do Colégio?" Sua sugestão foi recebida com aplausos [...]. (LIEBLING, 1983, p. 27).

O outro momento foi na escolha do lema da escola amada. Como integrante da primeira turma de formandas do Colégio Centenário, em 1926, Carlinda Shüller Liebling também participou, bem como na instituição do anel de formatura, tradição que acompanharia outras formaturas. A educação do corpo, da mente e do coração constituíram o núcleo desses dois símbolos da escola:

${ }^{3} \mathrm{O}$ Colégio Centenário foi fundado pelas missionárias metodistas norte-americanas Miss Eunice F. Andrew e Miss Louise Best, no ano de 1922.

${ }^{4} \mathrm{~A}$ autora não menciona o nome da interna referida. 
Esta turma teve o privilégio da escolha do lema do Colégio - "Educar a mente a pensar, o corpo a agir e o coração a sentir", bem como do anel de grau que se constituía de uma tocha em relevo, rodeada de abreviatura do lema: "Educar a mente, o corpo e o coração". (LIEBLING, 1983, p. 24).

Para a construção da nossa história da história de vida da professora Carlinda refletimos sobre uma entrevista que nos foi concedida por uma de uma de suas filhas, a dra. Lúcia Liebling Copite (LLC). Essa entrevista constituiu-se em um diálogo emocionante sobre pioneirismo e ousadia, encarnados por uma menina gaúcha que deixou o aconchego da sua terra de infância, Santana do Livramento, e se transferiu para Santa Maria, uma cidade grande, desconhecida e com hábitos distintos de sua cidade pequena da fronteira. Assim, ouvindo a narrativa da filha, refletimos não apenas sobre o conteúdo dos dizeres sobre sua mãe, mas, também, sobre os modos construídos por ela para apresentar esses dizeres. Assim, em nossa imaginação, nossa história foi tomando forma.

Precisamos registrar desde já, que muito colaborou com nossa história, o reverendo Cláudio Nelson Kiehl, que pastoreou a professora Carlinda na Igreja Metodista por muitos anos e que a acompanhou nos últimos momentos de vida. A leitura de um livro dela, publicado em 1983, no qual nos conta sua história do Colégio Centenário, "Centenário: uma história escrita com amor e por amor", foi feita com muito respeito e admiração. Porque foi assim que ela o escreveu: com muito respeito e admiração pela escola amada.

\section{Não perguntes onde fica... Segue o rumo do teu próprio coração 5}

Falar sobre alguém resulta falar de alguém. No entanto, ao falar sobre alguém fala-se também de si próprio, porque as palavras que escolhi para ter falado de alguém dizem (falam) também de quem as

\footnotetext{
${ }^{5}$ Analogia que, respeitosamente, fazemos da inspiração poética dos irmãos Nico e Bagre Fagundes, historiador e poeta gaúcho, ao cantar sua terra o Alegrete. Música. A música "O Canto Alegretense", é reconhecida como uma das mais importantes marcas que caracterizam o Rio Grande do Sul, sendo reconhecida nacional e internacionalmente.
}

escolheu (ou seja, de quem está falando: podem ser reveladora de atitudes do seu autor em relação aquele de quem ele se ocupa ao falar).

Assim, quando se fala junto com esse alguém sobre si (e, aqui, neste si está implicado tanto ele que se narra quanto eu que, ao ouvi-lo e fazer minhas perguntas, também estou, de algum modo, narrando-me a ele). Trata-se, portanto, de uma comunhão de propósitos, onde o que se instaura pelo diálogo é um processo de implicação mútua.

Quando a pessoa de quem se trata não está mais presente, podemos continuar a ouvir sua voz, presentificando-se nas vozes daqueles que sobre ela falam. Na pausa das falas, nas interjeições faciais e posturas corporais, pode ecoar o eco de sua voz materializado nessa pausa para que outras lembranças possam aflorar. Assim, de certa forma, a pessoa também participa dessa narrativa que os entrevistados realizam com o pesquisador, do mesmo modo ocorrendo quando este reflete no intervalo de um parágrafo em um texto dela por ele lido.

Na procura do rumo a ser seguido para a nossa construção, encontramos a possibilidade de trabaIharmos tendo em vista três dimensões a se intercruzarem: presentificação, sentimento, e continuidade. Presentificação. Se esta condição, nessa concepção por nós adotada como princípio básico a orientar nossa pesquisa sobre uma professora que já não está mais fisicamente entre nós, não estiver presente (mais do que isso, não for sentida por nós na construção da nossa história de vida de sua história de vida, o trabalho seria sem sentimento. Sentimento. Esta é a segunda condição que elegemos para nos ocupar de sua história de vida; precisaríamos sentir em que sua história de vida nos toca, mexe conosco, nos atravessa. E, por fim, continuidade. Foi porque, ao terminarmos nossos estudos sentimos que a sua história de vida não terminou de uma forma biográfica com início, desenvolvimento e fim, mas que tem potencial de ter continuidade, isto é, de continuar influenciando positivamente pessoas, nos resolvemos publicá-la.

Assim, para a construção desta história de vida, seguimos o rumo do nosso próprio coração... 


\section{Quando a escola é um lar que educa e o lar uma extensão da escola a educar}

Quando se lembra e se narra histórias da história de vida da professora Carlinda, lembra-se e narra-se também uma parte da história da Educação Metodista no Rio Grande do Sul: aquela ensinada e aprendida, aprendida e ensinada, nos ambientes do Colégio Centenário. Sua história de vida demonstra o amor que sentia pelo colégio, de sorte que estimulou seus familiares, esposo e filhas, a conviverem no clima da Escola. A sua própria casa era uma extensão do colégio que ela tanto amou.

Por isso, este escrito sobre Carlinda não se trata de uma biografia. Foi construído refletindo-se em perspectivas narradas a partir de vivências e de registros da memória de quem conviveu com ela, e que consegue manifestar, como um preito de reconhecimento e de carinho múltiplas histórias de vidas dessa educadora centenarista.

Para apresentar Carlinda é necessário perceber como o contexto da Santa Maria e do Colégio Centenário influiu no desenvolvimento da sua personalidade. A falta de uma escola grande no seu município de origem levou seu pai a buscar um novo colégio, que acabou se transformando no seu novo lar. Ilustra esse episódio de ela ter feito do colégio que a acolhera o seu novo lar, o fato de ela sempre retornar ao antigo Centenário para exemplificar às suas filhas o contexto que a ajudou na construção de sua subjetividade como professora. Em várias oportunidades, durante as férias, ela, acompanhada das meninas, passava longos dias pelas salas, corredores e pátios do Centenário. Fazia questão de demonstrar para as filhas como a Escola havia cultivado, em sua vida, valores humanos e cristãos que a fizeram ser quem se tornou. A professora Carlinda possuía um temperamento forte que a marcou como pessoa perfeccionista, humana e jovial, mas bem crítica. Com facilidade cativava e convencia as pessoas sobre seu modo de pensar. Isto, também pode ser considerado como traços de sua personalidade fortemente desenvolvidos pela educação metodista centenarista em Santa Maria.

É sabido, no entanto, que uma pessoa não é exclusivamente resultado da sua educação familiar ou escolar e nem somente de suas decisões autonomamente construídas. Mas interação com múltiplas vivências e experiências, indo, portanto, muito além do seu somatório. O contexto social, no qual a pessoa se constrói e reconstrói cotidianamente, tem, pois, sua importância nessa interação. Verifica-se assim, que uma instituição educacional, enquanto parte de um contexto social maior pode influenciar significativamente no desenvolvimento da pessoa.

Natural de Lajeado, RS, Carlinda Shüller Liebling teve sua infância ligada à cidade de Santana do Livramento, na qual chegou com dois anos de idade; uma cidade localizada na fronteira do Rio Grande do Sul com a República Oriental do Uruguai. Nela passou boa parte da infância e início da adolescência. Para entender seu jeito de ver e expressar o mundo e a vida, é preciso considerar essa época de sua formação de base.

À época, as oportunidades de escolarização em Santana do Livramento eram limitadas. Seu pai encaminhou-a, juntamente com a irmã Morena Shüller Pereira, para complementarem os estudos em Santa Maria, no Colégio Centenário, educandário recém instituído pela Igreja Metodista no coração do Rio Grande do Sul ${ }^{6}$. Segundo sua filha Lúcia, isso aconteceu no início da adolescência: "minha mãe foi estudar no Centenário, se não me engano, com uns $13 \operatorname{anos}^{7}$ devido às dificuldades[...]". Essa decisão teve como reforço, a sugestão do Rev. Álvaro Torres, pastor da igreja local, conforme Lúcia contou, sobre quem a tinha apresentado à Igreja Metodista naquela cidade fronteiriça: "[...] lá em Livramento [...] foi esse pastor que a levou para a igreja" (LLC).

Para Carlinda, o novo colégio, recém-inaugurado em 27 de março de 1922, passou a ser o seu segundo lar, visto tratar-se de um internato. Quando escreveu a história do educandário querido, fez menção

\footnotetext{
${ }^{6}$ No Rio Grande do Sul já haviam os colégios metodistas União de Uruguaiana (1870), Americano na capital (1885). O Educacional de Passo Fundo fora fundado no mesmo ano do Centenário. O Porto Alegre College (IPA) seria fundado no ano seguinte (1923). O União era colégio misto, desde a sua fundação. O Educacional e o IPA, masculinos. Colégios especificamente femininos, à época, eram o Americano e o Centenário.

${ }^{7}$ Carlinda foi para Santa Maria aos 16 anos, em 1922 (LIEBRING, 1983, paginação irregular).
} 
ao alvorecer da sua instituição: "quando te vi nascer, já sentia fé no ilimitado potencial que te faria avançar destemido no tempo, esparzindo luz. [...] e o amor era o elo indestrutível, unindo os corações que participaram de tua arrancada [...]" (LIEBLING, 1983, p. 11). Essa afeição pela escola é corroborada pela narrativa de sua filha Lúcia:

[...] a mãe estava sempre contando histórias do Colégio Centenário; ela vivia o Colégio Centenário; para ela o Colégio Centenário era a vida e na minha casa sempre tinha alguém hospedado que vinha do Colégio Centenário [...]. (LLC).

O Reverendo Cláudio Nelson Kiehl (CNK), pastor da Igreja Metodista na II Região Ecleisástica (RS), ao se referir às conversas que tinha com a professora Carlinda Shüller Liebling, também destacou o amor pela Instituição de tal sorte que ela se sentia, disse ele, como se fosse uma das fundadoras do Colégio.

Conversávamos muito sobre o Colégio Centenário. E quando tal assunto surgia, ela dedicava especial atenção ao fato de ter sido uma das primeiras alunas e internas do referido Colégio, juntamente com sua irmã Morena Pereira. O amor pelo Colégio Centenário era tanto que ela sentia-se como que uma das "fundadoras". Expressava muito carinho pelo Colégio Centenário, contando como era sua rotina como estudante e interna (horário de acordar, estudar, fazer as refeições, praticar esporte, etc). (KIEHL, 2014, p.1).

Outra percepção sobre esta marca do colégio na vida de Carlinda está no depoimento de sua filha Lúcia, quando se refere às férias passadas em Santa Maria, nas salas de aula, corredores, pátios e alojamentos do Centenário: "as férias de julho para mim era a maior alegria, porque eu ia para Santa Maria com a mãe e lá eu podia brincar à vontade; o colégio ficava para mim" (LLC). Isso também é corroborado em outra parte do seu depoimento, quando ela fala da permanência de sua mãe e de sua tia no Colégio no decorrer de todo o ano letivo:

[...] elas só iam uma vez por ano para casa; iam de trem e nas férias de julho elas ficavam no colégio porque era uma aventura elas irem de trem sozinhas; aí o meu avô teria que buscá-las em Santa
Maria e então elas ficavam lá; com isso elas fizeram muita amizade com aquelas professoras americanas que também ficavam ali no colégio e eram jovens. (LLC).

Não se trata apenas da percepção amorosa de uma filha a tecer considerações sobre as narrativas de proximidade entre a mãe e sua escola. Os testemunhos encontram fundamento nas palavras da própria mãe, ao introduzir seu livro sobre a história do Colégio Centenário, quando diz: “[...] as caras lembranças de um tempo feliz que ali passei (LIEBLING, 1983, p. 12).

Não era apenas nos eventos e festividades do colégio que esse envolvimento aparecia de maneira forte. O cotidiano de Carlinda era marcado por ensinamentos e valores vividos no Centenário. A proximidade com colegas e com professores demonstra, tanto nos referenciais da educação que ensinava às filhas, quanto no círculo de colegas, com as quais manteve proximidade até a sua morte:

\footnotetext{
A mãe trazia, no dia a dia dela, o colégio: ou ela referia algum dos professores ou alguma das colegas e tinha um grupo dessas primeiras alunas que a mãe foi amiga de conviver com elas, sempre que possível até o fim da vida, cada uma foi morrendo, a mãe foi uma das últimas, elas tinham uma ligação imensa e eu conheci vários alunos da mãe ou do Centenário mesmo. (LLC).
}

Valores aprendidos no colégio e cultivados no seio da família eram tão marcantes que pessoas que a conheceram somente em sua idade avançada, também os percebiam concretamente. $O$ pastor metodista que a acompanhou nos últimos anos de sua vida e dirigiu a cerimônia do seu sepultamento, testemunha sobre a forma carinhosa como sempre foi acolhido em sua casa:

Ela marcou nossas vidas com sua maneira simples de viver, expressando muito amor, carinho e respeito por nós, pastores. Sua fé era sentida no seu olhar, nos seus gestos e na sua maneira de acolher as pessoas. Na Professora Carlinda Shüller Liebling encontramos um apoio e, juntamente com ela, uma família que nos acolheu. Pessoa muito querida e inesquecível. (KIEHL, 2014, p. 1). 
É notório que não apenas a educação formal proporcionada por uma instituição, mas também a convivência diuturna em um ambiente que preserva e enaltece determinados valores humanos influi, e, em alguns casos, até determina elementos da constituição da personalidade das pessoas. $\mathrm{O}$ apego à Instituição e a iniciativa de fazer suas filhas conviver com o ambiente no qual desenvolveu significativa etapa de sua adolescência e vida adulta, caracteriza a importância que Carlinda atribuía aos valores cultivados e ensinados no contexto social daquela instituição.

No depoimento do pastor Cláudio Nelson Kiehl aparece o refino da linguagem, a maneira de expressar-se e o conhecimento que ela construiu no decorrer de sua formação educacional. Ela demonstrava desenvoltura em diferentes temáticas, utilizando linguagem apropriada:

Não temos muitas lembranças do que ela falava especificamente sobre educação, apenas percebíamos em sua linguagem e maneira de falar que, por ser professora, ela a valorizava. Era uma pessoa muito inteligente e culta, demonstrando conhecimento para dialogar sobre diversos assuntos. (KIEHL, 2014, p. 1).

A identificação com professores, seja na infância ou na adolescência, é um traço importante na formação da personalidade de uma pessoa. No caso de Carlinda, a identificação com a missionária determinou, em boa medida, o perfil de pessoa que viera a se tornar.

Ao ressaltar a importância do "velho mestre-escola" em sua formação, pois era a partir dele que se passavam os caminhos das ciências Freud (1914a) não deixou de sublinhar o quanto o aspecto relacional era-lhe mais digno de nota ao se lembrar de sua passagem pelo antigo ginásio, reflexão que nos remete ao amor de transferência e de suas relações com o amor (RAHME, 2010, p. 72).

O contexto social (e nele o familiar e o educacional) e a presença significativa de personalidades fortes como educadoras, marcaram profundamente a construção da história de vida da professora Carlinda. Seu desempenho e seu envolvimento com os estudos e a sua dedicação ao Colégio foram notados pela gestão da época. Tão logo terminou o curso secundário, foi convidada a se tornar uma das professoras da escola. A matemática se tornou a sua ciência.

Profundamente envolvida com a Igreja Metodista, Carlinda Shüller Liebling sempre dizia "presente" em suas múltiplas atividades. A Igreja também era seu lar. Foi a criadora do Grupo Dorcas ${ }^{8}$, dedicado à ação social. De alguma maneira a professora Carlinda Shüller Liebling teve conhecimento de uma ferramenta muito utilizada pelos pastores e estudiosos da Bíblia, conhecida como Chave Bíblica. Trata-se de um vocabulário em que ao invés de explicar o sentido dos termos ali contidos, identifica onde os principais vocábulos bíblicos se encontram nos diferentes livros e capítulos da Bíblia. Não satisfeita com o conteúdo que a edição dessa Chave continha, ela elaborou uma chave bíblica própria:

[...] surgiu um livro que ela procurava, não sei se vocês viram [...] eu só vi na casa da mãe [...] era um livro que por exemplo: memória, tinha todos os livros e capítulos da Bíblia que aparecia aquela palavra [...] e ela fez um pra ela, só que nós a perdemos; não consegui achar; ela fez, tudo aquilo que ela achava importante para o dia a dia dela, temas que ela achava que era de grande importância para ela, procurava e toda a vez que ela achava alguma coisa importante relacionado aquilo ela colocava lá naquele relatório que ela fazia da Bíblia. (LLC).

\section{Magistério: uma vocação realizada}

Carlinda Shüller Liebling cresceu no Colégio Centenário. Dele vieram inspirações para boa parte do seu viver. Um exemplo disso é a vocação para o magistério. Tão logo terminou seus estudos secundários, foi contratada como primeira professora formada na Instituição ${ }^{9}$. Essa inspiração para o ensino nasceu da forma como percebia o fazer pedagógico das

\footnotetext{
${ }^{8} \mathrm{O}$ Grupo Dorcas se constituiu num grupo de mulheres pertencentes à Igreja Metodista Central de Porto alegre, que desenvolvia trabalhos artesanais de cuja venda o resultado era empregado em ações beneficentes.

${ }^{9}$ Sua formatura aconteceu em 1926 (LIEBLING, 1983, paginação irregular).
} 
missionárias e de outras professoras do educandário. Recordando da mãe, Lúcia diz:

[...] ela achava assim uma coisa fantástica aquele trabalho que era feito [...] era uma forma de ensinar completamente diferente do que ela conhecia nos colégios de Livramento; essas moças missionárias elas tinham uma visão muito mais aberta de vida, tanto que a mãe fez coisas pra época [...] era uma coisa espantosa; a mãe jogava tênis... lá em Livramento, imagina, não é? (LLC).

A vocação para o magistério, efetivada pela convivência no Colégio Centenário, se estendeu para outras experiências como professora. Ao retornar para sua cidade de origem, Santana do Livramento, Carlinda se dedicou ao ofício das aulas: "[...] depois ela trabalhou como professora particular em Santana do Livramento; ela foi professora do Samuel Torres, do Alberto Torres; ela foi professora de todos eles; [...]" (LLC).

Impressiona como o existir de uma pessoa, muitas vezes, parece obedecer a ciclo que se completa de tempos em tempos. Aquele pastor metodista que incentivou os pais de Carlinda para completar os seus estudos em Santa Maria, acabou sendo beneficiado, anos mais tarde, pela presteza pedagógica da jovem professora. O Samuel e o Alberto, alunos de Carlinda, eram filhos do pastor metodista que indicou-lhe o Colégio Centenário.

A vocação para o ensino levou Carlinda em direção a uma ciência considerada fundamental para o conhecimento humano: "[...] a mãe era uma apaixonada pela matemática; [...] dizia que a pessoa depois que conseguia compreender a matemática ela se apaixonava perdidamente... deve ser... eu nunca compreendi e nunca me apaixonei" (LLC).

A predileção pela matemática estava em acordo com a sua forma de enfrentar desafios no cotidiano. A obsessão pela "coisa certa", no "lugar certo", a tornou uma perfeccionista em tudo o que fazia. Apesar de não ter predileção pela cozinha, quando se dedicava a fazer um alimento, tinha que obedecer aos mínimos detalhes:

[...] sábado de tarde ela sentava na cozinha, pegava todas as coisas e arrumava na mesa, tudo certinho; a balancinha: meia grama a mais ela já tirava [...] tinha que ser perfeito; ela sempre foi perfeccionista - isso é uma coisa que todo mundo reconhecia nela; e fazia tortas [...] coisas maravilhosas [...] (LLC).

O modo diferente de fazer educação, trabalhado no colégio metodista Centenário, impressionou Carlinda Shüller Liebling de tal forma que não apenas se tornou uma inspiração para seu próprio estilo, no magistério, como ampliou os seus horizontes de vida: tornou-se uma pessoa livre de condicionamentos próprios às meninas da sua época. Tratava-se de uma educação que preparava para a liberdade, na mesma dimensão que tornava a pessoa cônscia de seus atos e responsável pelas suas atitudes. Ainda que parecesse, à sociedade em geral, um escarcéu, a educação construída nessa instituição educacional metodista possibilitava-Ihe aventuras significativas para a felicidade. O testemunho da sua filha Lúcia mostra um pouco da visão que outras pessoas tinham a respeito desse tipo de comportamento assumido por Carlinda:

[...] era um escândalo, mais ou menos [...] ainda professora ela e uma amiga foram a Rio Grande; pegaram o Ita ${ }^{10}$ e foram para o Rio de Janeiro ... também foi um escândalo, porque ela... o colégio dava essa noção de liberdade com responsabilidade; a mãe era uma pessoa extremamente correta, tinha uma vida regradíssima, mas uma cabeça muito aberta [...]. (LLC).

Entre os valores que Carlinda Shüller Liebling trazia, como ensinamentos vivenciados no Centenário, estavam as noções de liberdade e de responsabilidade. Percebia que precisavam andar juntas, tanto no que se referia à sua postura diante da vida quanto naquilo que passava para suas filhas. Há um episódio, no contexto da igreja, que sinaliza essa postura: as mulheres estavam debatendo os excessos dos jovens, notadamente das moças que frequentavam a

\footnotetext{
10 "Ita era o nome que designava a classe de navios, ou qualquer um dos navios a vapor brasileiros, pertencentes à Companhia Nacional de Navegação Costeira, que faziam a cabotagem, transportando cargas e passageiros de norte a sul do Brasil, na primeira metade do século 20". (ITAS. Disponível em: http://pt.wikipedia.org/wiki/ltas. Acesso em: 26 mar. 2015).
} 
igreja à época. Quando o debate tomou corpo, Carlinda interviu, com firmeza, justificando a diversão das jovens daquele tempo traçando um paralelo com as adolescentes de antanho. A confiança na liberdade e na responsabilidade dos jovens precisava ser afirmada. Para fundamentar sua posição, ela falou da forma como educou e conduziu suas filhas:

[...] o que que é isso como pode essa menina ir ao cinema com o namorado [...] saem de noite, vão dançar, isso é uma vergonha! E começaram todo o grupo [...] estava lá o grupo todo a reclamar dos jovens que não era nem sombra do que é hoje. De repente a mãe chamou a atenção de todo o mundo e disse: vamos parar de reclamar, porque vocês estão aqui reclamando que os jovens isso, os jovens aquilo. A minha filha está aqui, está casada, com um fiIhinho, não vejo nada errado [...] é uma mulher que foi para a faculdade, está casada já está fazendo a segunda faculdade; trabalha, se sustenta; não vejo nada de errado [...] e não vejo nestas outras tantas que vocês estão reclamando [...] que bom que elas hoje [...] podem dançar, não têm aquelas bobajadas [sic.] da nossa época! Vamos combinar, hoje pode ser que elas vão lá pro escurinho no fusca, mas vocês pegavam a carroça e iam, não é? Então vamos para que isso? É bobagem. (LLC).

A carreira do magistério da professora Carlinda foi significativamente reconhecida por seus ex-alunos. Pessoas que com ela se educaram, têm palavras de apreço e reconhecimento para com a antiga mestra:

Sua capacidade como professora é até hoje ressaltada por seus ex-alunos - médicos, engenheiros, políticos - todos profissionais realizados que, a cada encontro, enaltecem as qualidades daquela que, ainda muito jovem, guiou-os no aprendizado da escola e da vida. (LIEBLING, 1983, paginação irregular).

A sua atuação como professora encerrou-se em 1940 , ano em que o mundo se via às voltas com o segundo grande conflito de proporções bélicas que o marcaria por todo o século XX, e também o ano em que ela se casou com Lothar Júlio Liebling, cidadão alemão que veio para o Brasil como representante comercial das Lâmpadas Osram.
A forma como a professora Carlinda desempenhava seu trabalho se reportava ao modelo de educação vivenciada desde sua época de interna no Colégio Centenário. Os mesmos princípios e os mesmos valores a acompanharam em toda a sua trajetória, no magistério, fazendo perceber-se nela um temperamento forte característico em sua vida.

\section{Temperamento forte}

O perfil perfeccionista cultivado pela professora Carlinda se manifestava ao ponto de incomodar às filhas em virtude de minúcias caprichosas, por exemplo, da confecção de um agasalho. Mesmo que a expectativa por um pulôver fosse para um evento social de final de semana, se não estivesse "perfeitamente" trançado, não seria usado pelas meninas:

[...] se ela tivesse que fazer casaco de tricô e descobrisse no último ponto que ela tinha errado lá no primeiro, ela desmanchava todo o casaco; a gente cansava; às vezes a gente estava esperando aquele pulôver que ela ia fazer pra gente ir na matinê do domingo; estava ali pra terminar e ela desmanchava; a gente dizia, ai mãe, pelo amor de Deus, ninguém vai ver; ela dizia, eu vou ver e é o que basta; [...] ela nunca admitiu ver uma coisa errada e passar por cima; [...]. (LLC).

Essa característica marcante em sua personalidade também influenciava na maneira de se relacionar com familiares e com outras pessoas. Havia uma grande proximidade entre ela e sua irmã Morena. Foram juntas para Santa Maria, a fim de complementar os seus estudos. Essa etapa da vida também contribuiu para aumentar a proximidade entre elas. Porém, isso não teria sido suficiente para evitar que, quando ambas ficaram viúvas não fossem morar juntas sob um mesmo teto:

[...] mas justamente por isso, elas moravam cada uma no seu apartamento. Tinham a sua individualidade. Minha mãe tinha as amigas dela, minha tia tinha as dela; tinham amigas comuns, geralmente as pessoas da igreja, mas elas tinham amigas... que não eram amigas da outra. Minha tia adorava cozinhar, minha mãe odiava cozinha; elas descobri- 
ram, quando o pai morreu ... as pessoas diziam, mas por que Morena tu não vai morar com a Carlinda Shüller Liebling? Imagina, ter dois apartamentos um do lado do outro ${ }^{11}$, cada um mora uma pessoa? E a tia Morena dizia: faço qualquer negócio com vocês, menos morar com a Carlinda, como ela também não quer morar comigo porque assim está ótimo! Quando eu me incomodo com ela vou pra minha casa; quando ela se incomoda comigo vai pra casa dela e a gente não briga; as duas tinham temperamento muito forte. (LLC).

O temperamento forte de Carlinda também era percebido por outras pessoas quando viam sua postura bem humorada e jovial, mas crítica em relação aos valores. Eram traços que refletiam a educação do Centenário, capaz de marcar o caráter de seus alunos e professores. Essa dimensão foi registrada por Lígia Militz da Costa, na apresentação do livro escrito por Carlinda Shüller Liebling:

Com seu jeito jovem e bem humorado de escrever, a Autora constrói um livro que questiona os padrões culturais e sociais da tradição, assumindo uma perspectiva crítica e renovadora que coincide com as proposições pedagógicas desenvolvidas pelo Colégio, no decorrer de sua evolução. (LIEBLING, 1983, p.10).

Outra característica desse temperamento forte se manifestava na capacidade de convencimento das outras pessoas. Seu marido dizia que se não houvesse certa firmeza naquilo que se acreditava, não seria recomendável deixá-la falar, pois ela seria capaz de convencer as pessoas a fazer a sua vontade: "[...] sempre ela conseguia fazer aquilo, como dizia o meu pai, não deixa ela falar, porque ela convencia as pessoas para fazer aquilo que ela queria;" (LLC).

O seu poder de convencimento também apareceu na decisão sobre o próprio casamento. Lothar era ateu declarado. Questões religiosas, de dogmas, ritos e costumes não faziam parte do seu cotidiano. Entretanto, Carlinda, com a firmeza que lhe era característica, convenceu seu noivo a casar-se na Igreja Metodista:

\footnotetext{
${ }^{11}$ Ambas moravam no mesmo andar do mesmo edifício localizado no centro de Porto Alegre, de maneira que podiam se enxergar pela janela de suas moradias.
}

[...] era uma coisa muito forte! Tão forte que ela convenceu meu pai de casar na igreja. Meu pai era ateu e ela convenceu meu pai a casar na igreja e o reverendo que depois foi bispo, o bispo Pinheiro [José Pedro Pinheiro] era um grande amigo do meu pai [...]. (LLC).

Questionada sobre as características da mãe que poderiam ser sentidas em sua própria vida, Lúcia se reporta a duas particularidades que marcaram a sua personalidade, ligadas à firmeza de propósito ensinadas e vividas por sua mãe:

[...] em algumas coisas sim: garra; quando eu decido que vou fazer, eu faço; pode haver o obstáculo que tiver vou em frente; teimosia; esse jeito assim de procurar acompanhar o desenrolar das coisas e não ficar rememorando o passado. (LLC).

A firmeza de propósito na professora Carlinda, incluía realização de seus desejos, especialmente aqueles ligados aos estudos. Quando a irmã Morena teve que voltar para Livramento, o pai tentou impedi-la de permanecer em Santa Maria. Entretanto, isso não foi suficiente; colocou-se diante do pai com argumentos irrefutáveis, ao ponto de fazê-lo permitir sua permanência no Centenário:

[...] não me lembro da mãe com medo de alguma coisa [...] imagina ela ficar lá em Santa Maria sozinha quando a minha irmã foi embora [...] com pessoas que ela nunca tinha visto na vida e [...] bateu pé e ficou [...] segundo me consta, o pai [dela] ficou muito bravo, mas ela domou ele até que ele deixou ela ficar e ela ficou [...]. (LLC).

A firmeza de caráter e de posições definidas não confundia sua postura em relação à dinâmica da vida social. Mantinha uma postura aberta em relação aos avanços da sociedade, tanto no que se referia às oportunidades de participação quanto à mobilidade educacional. Essa abertura de mente era reconhecida, inclusive, por pessoas do círculo de amizades das próprias netas. Comparada às senhoras idosas de seu tempo, Carlinda se posicionava bem além, como se vê no depoimento de sua filha Lúcia: 
[...] sempre lembro que as amigas da Luciane $^{12}$ ficavam muito encantadas como a minha mãe tinha uma cabeça aberta, porque as avós, diziam, eram pessoas de idade com a cabeça de uma época que elas nasceram; a mãe, apesar de ser mais velha que a maioria das avós, ela conversava com a Luciane sobre sexo[...] e as outras avós [...] meu Deus do céu[...] eram capaz de desmaiar; ela levava a Luciane para viajar com ela; ela ia ao cinema com a Luciane [...] e sempre estava por dentro de todos os assuntos. (LLC).

A postura aberta se ampliava na direção da crítica à sociedade contemporânea, comparava sua vida de interna com os avanços do progresso da década de 1980:

Por isso é tão difícil, para quantos viveram naquela época, aceitar os dias de hoje, apesar de estarem acompanhando o progresso que tem trazido em seu bojo, a par de um sem número de maravilhas quase inconcebíveis ao espírito humano, tanta poluição do espírito, geradora da violência, das frustrações, da poluição de toda a espécie, da ganância do poder socioeconômico e político, quando só consegue viver e conviver quem tem sorte e garra. (LIEBLING, 1983, p. 37).

A professora Carlinda Shüller Liebling exerceu o magistério seguindo princípios e valores aprendidos em sua vivência no Colégio Centenário. O cuidado com os detalhes, a firmeza de propósitos, sua autonomia de reflexão, a capacidade de convencimento e de guardar dados na memória, a determinação, faziam parte da sua forma de atuar na vida profissional e na vida pessoal.

\section{Espiritualidade esclarecida}

Nas características marcantes de sua personalidade, construídas no Colégio Centenário, estava o envolvimento com a Igreja Metodista. Como pessoa que não apreciava a rotina doméstica, ela sempre arrumava algum envolvimento fora dos limites do lar. A igreja era a sua instituição preferida. Quando aposentou-se, envolveu-se ainda mais com as atividades religiosas:

\footnotetext{
${ }^{12}$ Trata-se da filha de Lúcia.
}

\begin{abstract}
[...] ela já estava aposentada e a mãe nunca foi uma pessoa muito propensa a ficar em casa; ela gostava de passear, ela gostava de ter atividades, mas quando ela se aposentou ela tinha várias atividades na igreja, porque ficar assim sentada em casa não dava felicidade pra ela [...]. (LLC).
\end{abstract}

Essa percepção é corroborada pela entrevista do pastor metodista reverendo Kiehl (2014), quando se refere ao envolvimento que Carlinda tinha com a Igreja Metodista como "pleno". Enquanto sua saúde permitiu ela esteve presente nas atividades da Igreja. E mesmo a partir do instante em que a enfermidade Ihe limitou a mobilidade, continuou sua ligação com a comunidade, por meio do pastor e participando de eventos cristãos envolvendo os próprios familiares:

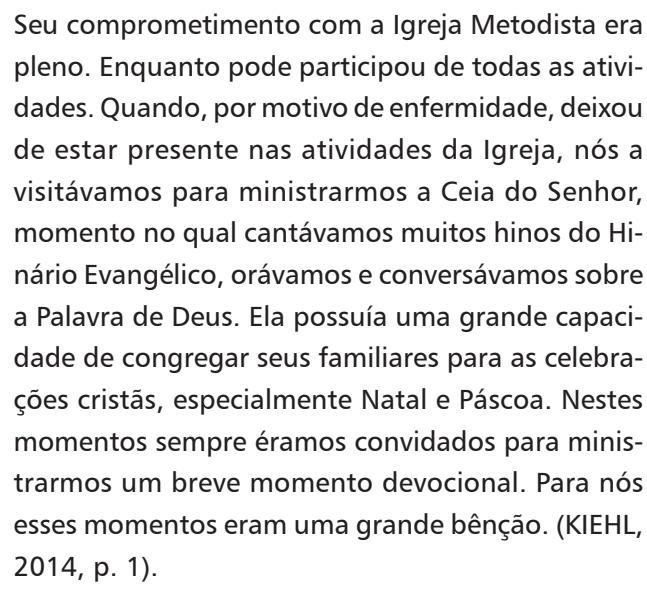

O envolvimento com a igreja tinha um caráter vital para a professora Carlinda Shüller Liebling. Ela não conseguia viver sem isso, pois desde pequena seu cotidiano estava relacionado à igreja. Sua infância foi marcada por esse relacionamento, notadamente pela forma como percebia e participava das atividades que a igreja proporcionava às crianças:

[...] mas pra mãe ela sempre dizia que se tirassem a igreja, tirariam a vida dela, porque ela desde pequena, em Livramento, ela conheceu um pastor que morava perto. [...] ela conheceu o metodismo com esse pastor lá em Livramento; ela e as minhas tias começaram a frequentar a igreja lá [...] os irmãos eram homens [...] só tinha ela e a minha tia Morena. Então elas iam na igreja porque elas achavam muito bonito, o culto, as brincadeiras com as crianças que na igreja Católica não tinha nada disso. (LLC). 
Entre as suas contribuições para a vida da igreja está a criação de um grupo especial de mulheres. Tratava-se do Grupo Dorcas ${ }^{13}$, cuja finalidade era realizar trabalhos manuais destinados a ajudar instituições beneficentes da própria igreja e de outras organizações de assistência social. Conforme o testemunho de Lúcia, Carlinda foi a fundadora: "[...] as senhoras que trabalhavam junto com a mãe [...] a mãe criou as Dorcas [...]" (LLC).

A convivência com a comunidade religiosa, nascida na infância e aperfeiçoada no Colégio Centenário, desenvolveu em sua personalidade uma marca de devoção e conhecimento da Bíblia. Da Bíblia provinham as palavras que lhe traziam a paz necessária nos momentos de fragilidade. Certa vez, enferma, precisou ser hospitalizada. No recinto do quarto, solicitava que as pessoas do entorno lessem a Bíblia. Quando o seu pastor a visitava, sempre pedia-Ihe que lesse um trecho bíblico: "[...] tanto que quando ela ficou mal no hospital, o Claudio ${ }^{14} \mathrm{e}$ a minha irmã ficamos repetindo porque o médico disse que ela não ia mais voltar e ela estava sofrendo muito e a gente ficou repetindo para que ela se acalmasse; [...]" (LLC). Sua predileção era pelo livro dos Salmos, mais especificamente pelo capítulo 23, cujo conteúdo se constitui numa prece de acolhimento e consolo:

[...] qualquer coisa que ela tivesse nervosa, tivesse preocupada ela abria a Bíblia e lia o Salmo 12315; não sei porque ela lia, porque ela sabia de cor, mas ela abria; acho que dava confiança; então quando a gente pegava, ela já dizia sozinha; ela conhecia a Bíblia de ponta a ponta; [...] (LLC).

Em algumas tardes, ela chegava a emendar com a noite, devido a concentração na leitura. A leitura era uma de suas atividades prediletas. Mesmo quando a situação não era de fragilidade, a Bíblia era sua

\footnotetext{
${ }^{13} \mathrm{O}$ nome do grupo, Dorcas, é uma referência ao livro de Atos 9.39 (Bíblia Sagrada, Novo Testamento), no qual aparece uma viúva que tinha esse mesmo nome e fazia obras de caridade.

${ }^{14}$ Tratava-se do Rev. Claudio Nelson Kiehl, pastor da Igreja Metodista Central, na ocasião.

${ }^{15}$ Deve se tratar do SI 23, visto que possui um conteúdo de consolo; o conteúdo do SI 123 é um cântico de desprezo e de fadiga para com os inimigos. (Observação nossa).
}

leitura preferida e um costume que a acompanhava, notadamente antes de se recolher ao leito:

[...] ela ficava lendo até tarde e gostava de ler na sala, não gostava de ler deitada; acho que era por causa do reumatismo que incomodava ela; mas na hora que ela deitava, ela lia a Bíblia; e todas as noites; a Bíblia dela estava ali e ela não admitia ${ }^{16}[. ..] \mathrm{e}$ ela até morrer ela não dormia sem ler a Bíblia. (LLC).

Há um episódio bastante interessante ligando seu esposo, ela e a Bíblia. Certa vez Lothar viajou e ao retornar trouxe-lhe uma Bíblia de presente. A princípio isso a deixou muito satisfeita, visto que seu marido, ateu, havia encontrado um presente para ela, ligado à sua religiosidade. Entretanto, esse episódio acabou se transformando em um motivo de desencontro com o marido. A filha Lúcia narra o episódio da seguinte maneira:

[...] até tem uma passagem engraçadíssima, [...] meu pai numa ocasião, pra mostrar que ele admitia a religiosidade da minha mãe ele foi ao Rio numa convenção da empresa e trouxe [...] ele se hospedou, não me lembro se era no Copacabana Palace ou Hotel Glória, só sei que era um hotel chiquérrimo, e ele trouxe uma Bíblia assim, pequena e a minha mãe ficou muito emocionada: o meu pai se lembrara de trazer uma Bíblia para ela! Aí ela abriu e tinha um carimbo: "Esta Bíblia foi roubada do Hotel [...]"; ela ficou tão brava, desmontou toda aquela emoção dela [...] olha aqui [...] retira isso aqui; mas eu trouxe, eu lembrei de ti; mas tu roubaste; ah eu não vi; estava lá e eu pensei que podia trazer; tu não viste que a Bíblia é um livro que todo o mundo tem que ter; mas não era nem porque tivesse o nome do hotel, mas dizia lá: esta Bíblia foi roubada; [...]. (LLC).

Sua inquietação perfeccionista também penetrou o estudo da Bíblia. Ela buscava a verdade em seu fundamento mais radical. Era capaz de até não concordar com alguma narrativa bíblica, porque não coincidia com a sua forma de ver. Sobre isso, Lúcia diz: “[...] fez um estudo muito profundo da Bíblia; a mãe nunca foi de aceitar muito as coisas porque alguém disse para ela, assim como ela não aceitava a

\footnotetext{
${ }^{16}$ Refere-se ao fato de que tinha que ser a sua Bíblia e não admitia que alguém a tirasse do seu quarto.
} 
Bíblia no que ela achava que não estava certo; ela lia, ela estudava [...]" (LLC).

O cuidado com a Bíblia incluía também o zelo que tinha pelo seu exemplar particular. Ninguém tinha o direito de mexer na "sua" Bíblia. Essa era exclusiva para o seu uso. Mesmo que estimulasse o apreço pela leitura, isso tinha que ser realizado em outro exemplar, nunca naquela de seu uso particular:

[...] a Bíblia dela, a Bíblia que eu conheci, sempre com ela, era uma Bíblia com papel de seda eu ainda tenho em casa; era quase como um papel de seda com umas letrinhas que acho que nem de óculos eu leio; ela mandou encadernar e tinha um fecho, em couro vermelho; ela fez aquilo e ela não gostava que pegassem [...] quando a gente queria ler, e ela incentivava a leitura, mas nas outras bíblias [...]. (LLC).

O envolvimento da professora Carlinda com a Igreja Metodista foi marcante, para ela e para a Igreja. Seu relacionamento com a comunidade, as iniciativas que tomava, os cuidado que tinha com a Bíblia e a educação cristã que proporcionou às filhas, demarcaram a seriedade com que tratou o compromisso com o Senhor e com a sua Igreja.

\section{Ética da alteridade}

Entre os valores cultivados pela professora Carlinda Shüller Liebling estava o respeito e a consideração para com as pessoas e suas formas de verem o mundo. Isso acontecia desde o interior do seu lar no conviver com o esposo, cujas ideias e forma de ser eram bem distintas das suas. No testemunho da sua filha Lúcia, isso fica bem evidente:

[...] a mãe era uma pessoa muito prática, ela não era uma pessoa romântica e o meu pai era o contrário e acho que era por isso que eles viviam muito bem; eles se respeitavam; uma coisa que a gente não via era o meu pai e minha mãe brigando. (LLC).

Lúcia também se reporta às diferenças entre os dois, mas ratifica sua percepção sobre a forma como o casal convivia em harmonia nessas diferenças. $O$ contraste entre a forma objetiva de fazer a vida, de Carlinda e o romantismo de Lothar, não impedia demonstrações de afeto e consideração entre eles:
[...] todos os sábados meu pai comprava flores para a minha mãe; era uma coisa assim que ele não deixava passar; e uma coisa que ele nunca esqueceu foi o aniversário dela ou o dia do aniversário de casamento; ele vinha com um presente, com uma flor, alguma coisa ele fazia. (LLC).

Carlinda não era atenta às particularidades de datas, como aniversários, bodas etc., "ela era desligada de tudo, essas coisas assim ela não ligava" (LLC). Quase não lembrava a data do próprio casamento. Certa vez Lothar estava fora, viajando, quando se aproximava a data de aniversário de matrimônio. Tentando compensar essa distração, Carlinda preparou uma surpresa, em comemoração ao dia do casamento. Imaginava que, uma vez que estivesse viajando a serviço, o marido teria esquecido a data das bodas. Quando ele chegou, convidou-o para jantar no restaurante, cujo local ela já havia preparado para o momento, mas algo não saiu como esperava:

[...] aí o pai estava viajando e ia chegar no sábado e a minha mãe disse, este ano vou fazer uma surpresa pro Lothar; meu pai se chamava Lothar; garanto, que com a viagem, ele esqueceu nosso aniversário de casamento, mas eu lembrei! Aí ela foi no centro, lá na praia e falou com um cara lá do restaurante, pediu uma comida que o pai gostava, pediu para arrumarem a mesa bonita e tinha um rapaz que tocava de noite lá no hotel; [...] à hora que nós viermos jantar aqui tu toca o "parabéns pra você...", que eu vou fazer uma surpresa pro meu marido [...] aí ela esperou ele, de noite ele chegou, ela se arrumou toda [...] naquela época a gente se arrumava para ir jantar e fomos para o restaurante; nós achando aquilo o máximo: agora a mãe vai fazer uma surpresa pro pai; chegamos no restaurante, o rapaz tocou o "parabéns a você" e o pai nada; o pai olhava e a mãe perguntou o que foi; e ele disse, quem é que está de aniversário? E assim a mãe disse: este ano que eu me lembrei tu esqueceste do nosso aniversário de casamento. Ele olhou pra ela disse: não, eu não esqueci, até te trouxe um presente, mas o nosso aniversário de casamento é amanhã, não é hoje. (LLC).

Pode se dizer que Carlinda Shüller Liebling não era uma pessoa desligada da vida, mas concentrada naquilo que considerava mais importante no momento. Esse tipo de situação acontecia, por vezes, 
por causa dessa excessiva concentração nos afazeres cotidianos: "[...] a gente lembrava sempre desses desastres; ela era bastante [...] não digo desligada das coisas assim, mas [...] ligada naquelas coisas do dia a dia $[\ldots] "$ ".. (LLC).

Sobre o tempo no qual desfrutou da vida no Colégio Centenário, Carlinda se reportava à disciplina interna. Percebia, que muitas vezes esta continha rigor de costumes e certa rigidez. Lembrava de colegas que eram consideradas mau exemplo, mas que fundamentalmente desejavam maior liberdade para dar vazão aos seus ideais:

Perdura a lembrança de algumas alunas mais exaltadas, revoltadas, consideradas até "mau exemplo" para as demais colegas, as quais, examinadas através do prisma do hoje, nada mais eram do que espíritos ansiosos por maior liberdade para atingir a concretização de seus sonhos e ideais. (LIEBLING, 1983, p. 36).

Perguntada sobre como sua mãe reagiria diante da possibilidade de ter sua história relembrada numa pesquisa de Histórias de Vidas, Lúcia se reportou à timidez de sua mãe, dizendo que ela chamaria os autores de "loucos": "[...] ela iria dizer, 'vocês estão loucos! Eu não tenho nada pra contar pra vocês, não quero saber de nada disso' [...] a mãe era muito tímida [...]." (LLC).

Mostrando ser acertada essa percepção da sua filha, constatamos que a professora Carlinda deixara registrado no livro que escreveu a sua dificuldade em lidar com questões de exposição pública. Nas comemorações do centenário da Independência do Brasil, no dia 7 de setembro de 1922, coube-lhe a missão de fazer o discurso de saudação. Momentos antes de iniciar o programa, ela teria sido apresentada ao autor do livro de História do Brasil que servira de fonte para a sua pesquisa. O seu relato ilustra significativamente a dificuldade que enfrentou:

Fugiu o chão debaixo de meus pés ao lembrar o discurso. Pagaria, naquele momento, para ver "a banda passar", mas nada era possível fazer em meu favor. Lá fui como ovelha para o matadouro. Desde então, neguei-me peremptoriamente a tomar parte em qualquer programa de comemorações [...] só quem é tímido e inibido sabe ao certo avaliar o desespero e a angustia que se sofre nesses momentos. (LIEBLING, 1983, p. 20).

Sobre os modos como construiu sua vida, a professora Carlinda imprimia uma trajetória focada nas coisas práticas do cotidiano. Sua prioridade se concentrava no que deve ser feito. Diferentemente do seu marido, mais romântico, ela buscava o necessário e o útil. O principal objeto de suas preocupações era a profissão, o trabalho que desempenhava no Ministério Público do Rio Grande do Sul. As questões ligadas à casa eram encaminhadas pelo marido e, na sua falta, pela empregada.

Tímida, quando era desafiada a se pronunciar em público sentia-se perdida. Por outro lado, ao defender suas ideias, posicionava-se criticamente com firmeza. Mas sempre numa atitude ética respeitosa à alteridade.

\section{Considerações finais}

A professora Carlinda Shüller Liebling desempenhava o ofício do magistério observando princípios e valores apreendidos no colégio metodista Centenário, escola que a marcou decisivamente, tanto na vida como no exercício de suas profissões, o Magistério e o Ministério Público. Mesmo depois de aposentada, as pessoas que tinham contato com ela percebiam a maneira de ser de uma professora, pela forma como utilizava a linguagem. Seu fazer pedagógico foi sempre inspirado numa maneira aberta de ver o mundo, conforme o ensino que recebeu das antigas missionárias que construíram o Centenário, Miss Best e Miss Andrew.

Por ter participado da primeira turma de internas, valorizava o Colégio Centenário de forma especial. Intimamente ela se sentia uma de suas fundadoras, percepção reforçada pelo fato de ter sido contratada como a primeira professora formada pela escola. A vivência no colégio representou um momento de muita felicidade, ao ponto de sempre retornar ao Centenário acompanhada das filhas e do esposo.

Sua participação na comunidade de fé da Igreja Metodista foi intensa. Idealizou e criou um grupo de mulheres dedicadas à ação social através de trabaIhos manuais. Esse envolvimento na comunidade 
também manifestava o seu amor e carinho na forma como acolhia as pessoas. O comprometimento com a Igreja pode ser sintetizado nesta frase dita pela sua filha Lúcia: "se tirassem a igreja, tirariam a vida dela". Pessoa devota, a professora Carlinda recorria à Bíblia nos momentos mais importantes e tinha especial predileção pelas palavras do Salmo 23 , que recorda o cuidado e o carinho de Deus para com os seus filhos e filhas.

O estudo evidenciou, entre outros entendimentos construídos em seu processo, que a tenacidade, a perseverança, o entusiasmo e a construção, manutenção e desenvolvimento cotidiano de uma forte vontade de sentido existencial marcaram sua vida no magistério e podem servir, não como modelo único, mas como um exemplo de como é possível sentir-se bem na docência. Assim, a professora pode ser alinhada aos antigos mestres da educação que continuam a ensinar com sua história de vida.

Para finalizar, lembramos aqui o que nos disse Lúcia, sobre o que sua mãe, a professora Carlinda Shüller Liebling, diria ao saber que estaríamos desejando escrever nossa história de sua história de vida: "Ela chamaria os pesquisadores de "loucos": [...] ela iria dizer, 'vocês estão loucos! Eu não tenho nada pra contar pra vocês, não quero saber de nada disso' [...] a mãe era muito tímida [...]." (L LC).

\section{Referências:}

ABRAHÃO, M. H. M. B. Memórias memoráveis: educadores sul-rio-grandenses em histórias de vida. Porto Alegre: Editora Universitária Metodista IPA/EDIPUCRS, 2013.

BAUMAN, Z. Amor líquido: sobre a fragilidade dos laços humanos. Rio de Janeiro: Zahar, 2004.

BAUMAN, Z. Modernidade líquida. Rio de Janeiro: Zahar, 2001.

DIAS, I.; GARIN, N.C.; TIMM, E. Z. A espiritualidade na construção das condições de bem-estar na docência. Ciência em Movimento. Porto Alegre, n. 26, p. 69-78, 2011.

ERIKSON, E. H. O ciclo de vida completo: versão ampliada com novos capítulos sobre o nono estágio do desenvolvimento, por Joan M. Erikson. Porto Alegre: Artmed, 1998.
FRANKL, V. E. Em busca de sentido. 37. ed., São Leoplodo/ Petrópolis: Sinodal/Vozes, 2015.

GARIN, N. C. O pensamento teológico de Isac Alberto Rodrigues Aço na perspectiva de Reino de Deus e Missão: uma contribuição para a reflexão teológica e a prática pastoral da Igreja Metodista. 2007. 280f. Tese (Doutorado) - Escola Superior de Teologia, São Leopoldo, RS, 2007.

KIEHL, C. N. Entrevista. Porto Alegre, Centro Universitário Metodista - IPA, 30 out. 2014. Entrevista a Norberto da Cunha Garin.

KOPITTKE, L. L.. Depoimento. Porto Alegre, Centro Universitário Metodista - IPA, 01 ago. 2014. Entrevista a Norberto da Cunha Garin e Edgar Zanini Timm.

LIEBLING, C. S. Centenário: uma história escrita com amor e por amor. Santa Maria, RS. Edição da Autora, 1983.

MOSQUERA, J. J. M. O professor como pessoa. 2. ed., Porto Alegre: Sulina, 1978.

MOSQUERA, J. J. M.; STOBÄUS, C. D.; TIMM, E. Z. O professor e o cuidado de si: perspectivando a própria vida como uma obra de arte. Por que não? Ciência em Movimento, n. 22, p. 47-53, 2009.

PAPALIA, D. E.; OLDS, S. W.; FELDMAN, R. D. Desenvolvimento humano. 10. Ed., Porto Alegre: AMGH, 2010.

RAHME, M. M. F. Laço social e educação: um estudo sobre o efeitos do encontro com o outro no contexto escolar. 2010. 454f. Tese (Doutorado) Universidade de São Paulo. Disponível em: http://disde.minedu.gob.pe/xmlui/bitstrea m/handle/123456789/1768/2010_Rahme La\%C3\%A70\%20social\%20e\%20educa\%C3\%A7\%C3\% A3o-\%20um\%20estudo\%20sobre\%20os\%20efeitos\%20 do\%20encontro $\% 20$ com $\% 200 \% 20$ outro $\% 20$ no $\% 20$ contexto $\% 20$ escolar.pdf? sequence $=1$. Acesso em: 26 mar. 2015.

SANTOS, Benedito Carlos Alves dos; RIBEIRO, Maria Cristina de Camargo, UKITA, Gilberto Mitsuo; PEREIRA, Maria da Paz; DUARTE, Walquiria Fonseca; CUSTÓDIO, Eda Marconi. Características emocionais e traços de as emocionais e traços de personalidade em crianças institucionalizadas e não institucionalizadas. Boletim de psicologia, 2010, vol. LX, n. 133: 139-152. Disponível em: http://pepsic.bvsalud.org/ pdf/bolpsi/v60n133/v60n133a02.pdf. Acesso em: 26 mar. 2015.

TIMM, E. Z. Histórias de Vida: autorias recíprocas? In; ABRAHÃO, M. H. M. B; BOLÍVAR, A. (Orgs.). La investigación (auto)biográfica em educación: miradas cruzadas entre Brasil y España. Granada/Porto Alegre: EUG/EDIPUCRS, 2014. p. 174-192. 
TIMM, E. Z. A vida como uma obra de arte: pensando em histórias de vidas. In: ABRAHÃO, M. H. M. B. (Org.). (Auto) biografia e formação humana. Porto Alegre: EDIPUCRS, 2010. p. 45-62.

TIMM, E. Z.; GARIN, N. C.; SILVA, C. A.; FOGAÇA, D. A. Religião, confessionalidade, espiritualidade e educação: dimensionando possibilidades conceituais para suas relações no contexto da contemporaneidade. Revista de Educação do COGEIME. Porto Alegre, n. 48, p. 123-143, 2016.

TIMM, E. Z.; ABRAHÃO, M. H. M. B. A história de vida na docência na Educação Superior e o desenvolvimento humano do professor. Revista de Educação do COGEIME. Porto Alegre, n. 46, p. 123-143, 2015. 